Conference Paper

\title{
K-Pop Marketing Tactics That Build Fanatical Behavior
}

\author{
Andri Ardhiyansyah*, Dwi Putri Maharani, Sintia Permata Sari, Umar Mansur \\ Nusa Putra University, West Java, Indonesia
}

${ }^{*}$ Corresponding author:

E-mail:

andri.ardhiyansyah@nusapu-

tra.ac.id

\begin{abstract}
Kpop fans are known for their loyalty, they support their idols by buying albums, streaming music videos (MV), following concerts, fan meetings, fanservice, and many more. K-Pop fans are synonymous with fanaticism where K-pop fans are never separated from goods or merchandise related to their idols such as albums, lightsticks, photo cards, and other merchandise or by coming to every fan meeting, fan sign, Showcase, and idol concert. K-Pop fans are always considered excessive and always consumptive, and fan fanaticism is shown by joining the K-Pop fan community as their existence in providing information about K-Pop idols. This study aims to collect and analyze articles related to K-Pop marketing that causes fanaticism towards K-pop fans. The design used is a literature review, a critical analysis of the research being carried out on a specific topic of a scientific section. articles are collected using search engines such as Scopus and Google Scholar. Based on the articles collected, it is found that an interesting album and a concert that makes a happy experience can build a sense of love that leads to fanatical behavior. The album marketing strategy carried out by the South Korean entertainment agency makes K-Pop fans consume which is not only driven by efforts to meet their needs, but they have a sense of satisfaction from buying the K-Pop album
\end{abstract}

Keywords: K-Pop, hallyu, marketing, fanaticism

\section{Introduction}

Currently, the existence of K-Pop is familiar; the development of the spread of Hallyu or the wave of Korean culture is increasing. In Asia, almost the entire world is affected by K-Pop fever and has even penetrated the mainstream market to compete with world-famous musicians. Recently the boy group of Bangtan Boys, known as BTS, returned to bring home the 2020 Billboard Music Awards (BBMAs) Top Social Artist after winning it for four consecutive years (written by Yonhap on The Korea Herald, October 2020).

Apart from BTS, other Korean idols, namely Blackpink, EXO, Monsta X, NCT 127, ITZY, and others, have successfully entered the American Billboard from Billboard 200, Billboard Artist 100, Billboard World Albums, which are updated every week. This proves that the popularity of K-Pop is not a figment. K-pop fans are known for their loyalty; they support their idols by buying albums, streaming music videos (MV), attending concerts, fan meetings, fanservice, and many more. Some fans even buy hundreds of the same albums to collect all members' photocards in the album. Besides, K-Pop fans take advantage of social media such as trending their idol's name on Twitter, forming a fanbase with information about idols and creating humorous content to attract the public's attention. The things above can happen because fans who already like they don't care about them have sacrificed a lot of time, though, and money.

Kpop company agencies take advantage of fan loyalty to increase profitability. One example is collaborating to be a brand ambassador for a company or making items related to idols. The agency knows very well that fans will buy the product. Of course, love has a positive impact, but excessive love will cause harm.

\section{How to cite:}


Sasaeng is a very obsessive fan. According to Pintani Linta (2013) Sasaeng fans are categorized as fanatical. Sasaeng fans pursue their satisfaction to be close and talk to their idol artists. This satisfaction must be achieved even using dangerous means.

As experienced by D.O one of the EXO members. One of the sasaeng posted a pair of underwear allegedly belonging to D.O. In the post Sasaeng offered to sell underwear for 100,000 won (\$ 94), he said he had taken the item from his dormitory and it was very difficult to get it. written by KH Digital2 in The Korea Herald, January 2014). Fanaticism is a belief in a fanatical object which is then associated with something excessive in an object; this fanatical attitude is shown by activity, extreme enthusiasm, emotional attachment, and a feeling of love and excessive interest that lasts for a long time (Eliani et al., 2018).

Fanaticism starts from a sense of liking and admiration. It can be seen from fans' enthusiasm for their idols because fanaticism is identical to excessive fanatical objects' enthusiasm. The love and admiration that fans develop because of the addiction or addiction that K-Pop fans have; can be seen from the intensity they spend time with their idols (Putri, 2019). After that, the desire to have items related to their fanatical object will be realized from K-Pop fans' desire to buy items related to their idols such as t-shirts, music albums, photo cards, posters, and light sticks.

Based on the phenomena described earlier, the researchers are interested in researching and analyzing how K-Pop marketing can cause fanaticism towards K-Pop fans. The purpose of writing articles is intended to provide an overview of the relationship between K-pop marketing and fanaticism so that it can be used as a reference for readers.

\section{Literature Review K-Pop}

Korean Pop or abbreviated as K-Pop is the most popular music genre self from pop, dance, electropop, hip hop, rock, R\&B, and electric music originating from South Korea. Apart from music, $\mathrm{K}$-Pop is becoming popular, especially among teenagers to adults worldwide, through interesting singer and dance performances to follow. K-Pop is a type of music that carries the dance-pop genre or is defined as pop music combined with charming faces and dancing abilities and added by lyrics in songs that use Korean combined with western in certain parts (Nastiti, 2010).

$\mathrm{K}-\mathrm{Pop}$ is the production of pop products in hybridization that combines East and West and aspects of global and local culture (Chua \& Iwabuchi, 2010). The main reason for cultural hybridization is to fulfill the complex desires of various consumer groups that maximize capitalist profits, including in K-Pop itself such as all kinds of music programs from bands, boy bands, or vocal groups to dance, to Original Soundtracks of films or dramas and all other kinds of music.

The K-Pop market started as a music-intensive show that shifted to dance-intensive as musician Rain's influence with his extraordinary dancing skills. Regarding the language barrier, the dance-intensive segment doesn't make it a problem like the music-intensive segment. As a result, more and more people are learning Korean. In 1997, 2,274 people took the Test of Proficiency in Korean, and the number increased to 44,477 people in 2010. (Korea Times. "About The Test." TOPIC).

\section{Hallyu}

The K-Pop wave or called Hallyu (한), is a musical culture phenomenon that involves the deliberate spread of K-Pop (Korean popular music) to audiences around the world (Williams \& Ho, 2014). Since 2000, K-Pop artists such as BoA, Big Bang, Super Junior, Girls' Generation, SHINee, and others have been at the forefront of the Hallyu wave industry and have a clear fandom.

Hallyu has spread throughout the world, not only in Southeast Asia, but Hallyu has spread to the United States, Latin America, and the Middle East (Nastiti, 2010). Based on a report issued by the Korean Foundation, a foundation affiliated with the South Korean government per the year 2019, recorded there 1,843 Hallyu fan clubs K-Pop fans are scattered on 113country. One thing 
that must be understood when trying to understand the Hallyu phenomenon is that the global trend of K-Pop is not a coincidence. Hallyu is the result of a systematic collaboration between the government and the private sector in developing the creative industry in South Korea, triggered by the $1997 / 1998$ financial crisis.

Hallyu is a popular cultural phenomenon that, with its influence covering the fields of South Korean popular culture products such as film, music, food, and fashion, has hit almost worldwide. Hallyu is growing because it has the full support of the South Korean government and entertainment agencies and support from telecommunications agencies. The spread of Hallyu is getting wider.

\section{Marketing}

Marketing is a social process in which individuals and groups get what they need and want by creating, offering, and freely exchanging products that are valuable on the other hand (Kotler \& Keller, 2016).

Marketing is the overall system of business activities shown to plan, determine prices, promote and distribute goods and services that can satisfy existing and potential buyers (Swastha \& Irawan, 2005).

Marketing management is the process of analyzing, planning, coordinating, and controlling programs that include the concept, pricing, promotion, and distribution of products or services designed to create and maintain profitable exchanges to achieve company goals. Marketing is a social and managerial process where individuals and groups get their needs and desires by creating, offering, and exchanging things (Daryanto, 2011).

The marketing system aims to maximize consumption, maximize consumer satisfaction, choice, quality of life, and improve quality, quantity, availability, price, and profit. Marketing objectives can be created by analyzing the marketing mix, a set of marketing tools that companies use to continuously achieve their marketing goals in target markets.

\section{Fanaticism}

Fanaticism is a belief in a fanatical object that is associated with something excessive in an object; this fanatical attitude is shown by activity, extreme enthusiasm, emotional attachment, and a feeling of love and excessive interest that lasts for a long time (Eliani et al., 2018).

Fanaticism is defined as extraordinary devotion to an object, where "devotion" consists of passion, dedication, and "extraordinary" means beyond the ordinary, ordinary, or level. Objects can refer to a brand, product, person (such as a celebrity), television show, or other consumption activity. Fanaticism tends to insist on the ideas of those who consider themselves or their group to be right and ignore all facts or arguments that may conflict with their thoughts or beliefs (Chung et al., 2008).

Fanaticism is a very important phenomenon in modern culture, marketing, personal reality, and social society. Today's culture has a huge influence on individuals, and the relationships that occur within individuals create a belief and understanding in the form of relationships, loyalty, devotion, love. And so on (Seregina, et al., 2011).

Fanaticism is a broad study that can be viewed from various cases and different perspectives when someone is fond of an object or subject will be fine if this worshiping behavior is carried out, the problem in fanaticism is when this behavior has developed into behavior that can be dangerous. or hurt someone else. Fanatical behavior shown by fans often leads to negative behavior such as aggressive behavior (Marimaa, 2011).

Fanaticism is one of the drivers of aggressive behavior, such as verbal aggression which is carried out with the aim of hurting, arguing, and showing dislike or disapproval, individuals with fanaticism tend to boast of what is on their side or what they believe will be characterized by attitude fanatic. 


\section{Methodology}

The method used in this research is a literature review, which contains a description of the theory, findings, and other research materials obtained from reference materials to be used as a basis for research activities. This study using a journal literature search using the Scopus database and Google Scholar. In the early stages of searching for journal literature, 541 journals were obtained using the keywords "K-pop" and "K-Pop Fanaticism," which were then identified by articles to be compiled. From this number, eight journal literature was considered relevant and following this study.

\section{Result}

Based on the journal literature results collected, and according to the researcher's analysis, it was found that K-Pop fans are categorized as fans who have high loyalty to their idols. K-Pop fans are synonymous with fanaticism. K-pop fans are never separated from goods or merchandise related to their idols such as albums, lightsticks, photo cards, and other merchandise or by coming to every fan meeting, fan signs, showcase, and idol concert.

Merchandise is one of the popular things among K-Pop fans. Collecting merchandise is a form of activity carried out by fans, such as collecting products related to idols, official (official merchandise), and unofficial (unofficial merchandise).

In general, pleasure is understood broadly to include all pleasant feelings or experiences, contentment, joy, serenity, and so on. K-Pop fans claim to get pleasure from buying items related to their idols. Besides, K-Pop idols' abilities and physical appearance make it a special attraction for everyone or fans who see them.

\section{Discussion}

K-Pop fans have their designation, namely K-Poppers and K-Pop idols forming their community in each boy band and girl group, which has a fandom name. Fandom is a term used to refer to subcultures, things, and activities related to fans and their hobbies (Hollows, 2010). K-Pop fans are always considered excessive and always consumptive. Fan fanaticism is shown by joining the K-Pop fan community to provide information about K-Pop idols.

The digitalization implementation of the K-Pop music industry changes consumer buying behavior, behavior because initially fans only buy goods according to their needs. Nowadays fans buy an item because it is to show social status, price, and to satisfy desires, plus K-Pop fans have high efforts to support their idols. Seabrook (2012) suggests that a key element of South Korean culture's success is cultural technology, a strategic marketing framework used by South Korean media companies to promote cultural products to local and foreign consumers.

a. Album

The album is one of the important products that must be owned by K-Pop fans; each album has at least two to three versions of the album released. Besides that, CDs of songs are found in K-Pop albums, but other components such as photobooks, photocards, and different posters that make K-Pop albums have their charm, so that many fans are willing to pay to collect them.

The album marketing strategy carried out by South Korean entertainment agencies is by issuing and selling albums that have different versions and adding benefits such as photo cards, posters, bookmarks, photobooks, and others make K-Pop fans consume which is not only driven by efforts to meet their needs, but they have a sense of satisfaction from buying these K-Pop albums. K-Pop fans realize that they have been exploited so that they buy and collect albums in large numbers as the identity of a fan.

An album is also a form of support that fans directly show to their idols because album sales are one of success and popularity for K-Pop idols. 


\section{b. Concert}

Besides albums, concerts are also important because participating in a concert will have a different feeling than just buying an album. Listening to songs sung directly by idols, interactions that occur in front of the eyes, and other excitement create a strong emotional bond by providing happy experiences that lead to excessive love and lead to fanatical behavior.

This is following Bristow et al.'s opinion regarding fanaticism, which starts from a high sense of love and admiration, which can be seen from how the enthusiasm shown by fans when it comes to Kpop idols fanaticism is identical to excessive enthusiasm for fanatical objects.

\section{Conclusion}

Overall, fanatical fanaticism is the behavior or activity carried out excessively as a result of admiration for idol artists. Fanaticism can be positive or negative, which is deeply believed, making it difficult to correct or change.

The album marketing strategy carried out by South Korean entertainment agencies makes KPop fans consume which is not only driven by efforts to meet their needs, but they have a sense of satisfaction from buying these K-Pop albums. K-Pop fans realize that they have been exploited so that they buy and collect albums in large numbers as the identity of a fan.

K-Pop fans are synonymous with fanaticism because they are never separated from goods or merchandise related to their idols, whether official (official) or unofficial (unofficial) merchandise. Fan fanaticism is shown by joining the K-Pop fan community, purchasing albums, and attending idol concerts as a form of support that provides experience and love for their idols.

\section{Acknowledgment}

We thank all valuable comments from the anonymous reviewer and conference participants at 1st ICEMAC 2020. Sukabumi, 19-20 December 2020

\section{References}

Chua, B. H., \& Iwabuchi, K. (2010). East Asian pop culture: Analyzing the Korean wave. Hong Kong: Hong Kong University Press. Chung, E., Beverland, M., Farrelly, F., \& Quester, P. (2008). Exploring consumer fanaticism: Extraordinary devotion in the consumption context. America: ACR North American Advances.

Daryanto. (2011). Sari kuliah manajemen pemasaran. Bandung: Satu Nusa.

Eliani, J., Yuniardi, M. S., \& Masturah, A. N. (2018). Fanatisme dan perilaku agresif verbal di media sosial pada penggemar idola K-Pop. Psikohumaniora: Jurnal Penelitian Psikologi, 3(1), 59.

Hollows, J. (2010). Feminisme, feminitas, dan budaya populer. Jakarta: Jalasutra.

Kotler, P., \& Keller, K. L. (2016). Marketing management 16eth Edition. New Jersey: Prentice-Hall

Marimaa, K. (2011). The Many Faces of Fanaticism. ENDC Proceedings, 14, 29-55.

Nastiti, A. D. (2010). Korean wave di Indonesia: Antara budaya pop, internet, dan fanatisme pada remaja. Journal of Communication, $1(1), 1-23$.

Putri, A.W. 2019. BTS, 'ikon ekonomi' anyar Korea Selatan. Tirto.id. Access on https://tirto.id/bts-ikon-ekonomi-anyar-korea-selatanegjM pada 12 September 2020.

Seabrook, J. (2012). Factory girls: cultural technology and the making of K-Pop. New York:Newyorkers

Seregina, A., Koivisto, E., \& Mattila, P. (2011). Fanaticism-its development and meanings in consumers lives. Journal of Aalto University School of Economics. 1 (1), 1-106.

Swastha, B., \& Irawan. (2005). Menejemen pemasaran modern. Yogyakarta: Liberty.

Williams, J. P. \& Ho, X. X. S. (2014). 'Sasaengpaen' or K-pop fan? Singapore youths, authentic identities, and Asian media fandom. Deviant Behavior, 37, 81-94.

Yonhap, 2020. BTS wins fourth Top Social Artist prize at Billboard Music Award. Access on Source:http://www.koreaherald.com/view.php?ud=20201015000762 